Selecting Profitable Hotel Sites at La Quinta Motor Inns

\author{
Sheryl E. Kimes \\ School of Hotel Administration \\ Cornell University \\ Ithaca, New York 14853 \\ James A. Fitzsimmons \\ Department of Management \\ University of Texas \\ Austin, Texas 78712
}

Final version published in Interfaces (1990), 20(2), 12-20 


\begin{abstract}
Selecting a good site plays a crucial role in the success of a hotel, and as competition intensifies in the lodging industry, it has become increasingly important. The success of a site is based on competitive, demographic, physical, market awareness, and demand generator variables. We built a regression model for La Quinta Motor Inns, a mid-sized hotel chain headquartered in San Antonio, Texas, that predicted profitability for sites under consideration. We validated the regression model on new data and incorporated it into a spreadsheet decision model that management uses for selecting sites. The model minimizes the risk of picking an unprofitable site.
\end{abstract}




\section{Selecting Profitable Hotel Sites at La Quinta Motor Inns}

Location is one of the most important decisions for a lodging firm. Of the four major marketing considerations; price, product, promotion, and place, place and product have been shown to be the most important for multi-site firms with price and promotion playing secondary roles [Langeard and Eiglier 1983]. All hotel chains search for ideal locations and, in many cases, compete against each other for the same sites. A hotel chain that can pick good sites more accurately and quickly than its competition has a distinct competitive advantage.

The subject of this study, La Quinta Motor Inns, a moderately-priced hotel chain, discovered that competing firms were trying to enter its market niche: it is oriented towards serving the frequent business traveler. With intensified competition, the chain sought ways to maintain and increase its market share. La Quinta sought to protect its position through a careful analysis of its past location decisions in an attempt to predict the success of future sites.

We collected data on 57 mature inns belonging to La Quinta during a three- year business cycle. We conducted site visits and mapped the market area of each hotel and identified all demand generators and competition within a four- mile market area. We obtained other information from chambers of commerce, tourist bureaus, and the Bureau of the Census. 


\section{Choice of Modeling Procedure}

The issue of service site location has been studied extensively [Huff 1962;

Applebaum 1966; Craig, Ghosh, and McLafferty 1984] but most of the models that have been developed are appropriate only for services that draw their business from the immediately surrounding area. However, hotel guests are attracted to a site for its convenient location as defined by their travel needs. We wanted to identify the characteristics of hotel sites that would predict their attractiveness to potential guests. We used regression to model hotel selection behavior and predict the success of a site.

Regression models for location problems have traditionally been beset with problems ranging from lack of specificity on variable measurement to statistical overfitting and multicollinearity [Craig, Ghosh, and McLafferty 1984]. In addition, it is sometimes hard to define the market area of a business, and very few location regression models have been validated on additional data.

Faced with these potential hazards, we sought to design our study and modelbuilding procedure in such a way as to minimize their possible effects. For example, an extensive study of the market area for nine hotels in this chain [Tallis 1983] showed that 80 percent of its customers visited destinations within four miles of the inn. We defined variables very clearly to facilitate accurate data collection and measured them for the four-mile market area. We took care in developing the model to avoid the problems of overfitting and multicollinearity. Specifically, we used regression diagnostic tools [Belsely, Kuh, and Welsch 1980] to assess problems with multicollinearity, near collinearity and influential outliers. Finally, we made extensive efforts to validate the final 
model on both additional data sets and for different points in time for the original data set.

\section{Stages of Model Development}

We developed the model in several stages: (1) we selected and defined variables, (2) we performed exploratory data analysis, (3) we performed a correlation analysis, (4) a t-test analysis, (5) a regression analysis, (6) we developed the decision model, and (7) validated it.

\section{Selecting and Defining Variables}

We conducted extensive interviews with decision-makers at La Quinta to ascertain which variables entered into their location decisions. Several people made location decisions for the firm, including the director of marketing research, the vicepresident for development, the vice-president for real estate, the president of the firm, Sam Barshop, and four site evaluators. The president had the final word. Most of the people involved had a great deal of experience in real estate development and based their decisions on past performance and their gut feelings about the site.

Based on these interviews and other relevant literature, we classified possible independent variables as competitive, demand generator, demographic, market awareness, or physical site (Table 1). Competitive variables included the number of hotel rooms in the vicinity and average room rates. Demand generators were such local attractions as office buildings and hospitals which draw potential customers to the trade area (within a four-mile radius of the hotel site) [Tallis 1983]. Certain demographic 
characteristics in this trade area, such as the local population and the unemployment rate, can affect the success of a hotel. Market awareness factors, such as the age of the inn or the number of inns in a city or state, indicate some degree of market penetration and the likelihood that the inn is considered a lodging alternative. The physical characteristics of the site, for example, ease of access or sign visibility, can facilitate customers' arrival at the inn.

Choosing a dependent variable was more troublesome. Occupancy, the logical dependent variable, proved to be a very unstable indicator of success, especially considering the turbulent economics during this study [Kimes 1987]. We considered several other potential variables, such as total revenue or total profit, but they were too highly correlated with the size of the individual inn. We settled on forecasting operating margin (a percentage), which consisted of adding depreciation and interest expenses to the profit of the firm and dividing by the total revenue. Operating margin can be somewhat misleading because of the differing revenues in the denominator. Certainly, a 10 percent profit on $\$ 10$ million revenue is preferable to a 10 percent profit on $\$ 10$ thousand revenue. Operating margin is not correlated with the size of the inn and provides a better measure of success than does occupancy. Occupancy levels can be high while the firm is operating at a loss. In the final analysis, management needs a high operating margin to insure financial success. Occupancy is a poor surrogate for this goal. 


\section{Exploratory Data Analysis}

We analyzed the distribution of the values of both independent and dependent variables with exploratory data analysis (EDA) [Tukey 1977] and made suitable transformations so that the distribution of values approximated a "normal-like" distribution. EDA can be viewed as providing a systematic basis for analysis at a stage prior to applying standard methods of statistical inference. As its name suggests, EDA is an exploratory approach to data analysis and gives the researcher visual tools with which to examine the data structure of individual variables.

\section{Correlation Analysis}

The variables that consistently correlated with operating margin included the age of the inn (the older, the better), the distance to the downtown area (the closer, the better), the unemployment rate (the lower, the better), the distance to the nearest same brand inn (the closer, the better), local population (the higher, the better), the inn price (the higher, the better), the state population per inn (the lower, the better), the urban population per inn (the lower, the better), and the amount of hospital space (the more, the better) (Table 2).

To translate this into terms that are useful to La Quinta in making decisions, inns tended to do better in areas where the brand had high market penetration and awareness (an older inn, near other same brand inns, where penetration of the state and urban market was better).

In addition, several demand generators, such as the amount of hospital space and the local population had positive effects on profitability. Inns in areas with low 
unemployment rates (economically strong areas where higher prices could be charged) also tended to do better.

In addition, the accessibility of the site (the easier, the better), the amount of office space in the downtown area (the more, the better), sign visibility (the higher, the better) and traffic count (the higher, the better) were important variables in 1983. In 1986, the number of college students (the larger, the better), the presence of a nearby military base (the more people stationed at the base, the better), the median income of the market area (the lower, the better), and the competitive room rate (the higher, the better) all had significant correlations with profitability.

\section{T-Test Analysis}

Highly profitable inns were very different from unprofitable inns (Table 3). We defined profitable inns as those with an operating margin of greater than 50 percent and unprofitable inns as those with an operating margin of less than 30 percent. Profitable inns had more nearby college students, hospital beds, military bases, and office space. Profitable inns were in areas with better market penetration and tended to be located in areas with lower unemployment rates.

We conducted analyses for both 1983 and 1986. In 1983, profitable inns were located in areas with less competition and less tourism. In 1986, this situation reversed, and profitable inns were located in areas with higher levels of competition and tourism.

Several variables were significant in one year but not the other. For example, in 1983, profitable inns were located in areas with lower airport volume, were nearer other same brand inns, and had better sign visibility, whereas in 1986, profitable inns were 
nearer downtown areas, were in areas with higher local population, and were in locations with high traffic counts. In 1986, profitable inns were located in market areas with more office space than unprofitable inns.

\section{Regression Analysis}

We used the variables we found to be significantly correlated with profitability to build a regression model. We applied extensive diagnostic procedures to the resulting model to check for possible collinearity and outlier problems. We standardized all data to a mean of zero and a standard deviation of one to eliminate the possibility of scaling problems.

The regression model was 39.05

-5.41 * State population per inn (1000)

+5.86 * Price of the inn -3.09 * Square root of the median income of the area (1000)

+1.75 * College students within four miles (1000)

This model resulted in an R-squared of .51 , which indicates reasonable predictive ability, and a condition number of 2.52 , which indicates no serious problem with collinearity. In the course of the analysis, we realized that one inn was such a severe outlier that we eliminated it from the data set. Upon its removal, the model accuracy and stability improved dramatically.

Basically the model shows that profitability is affected by market penetration, positively affected by the price of the inn (which is a function of the competitive room rate of the market area), negatively affected by higher median incomes (the firm does 
better in areas with a lower median income, possibly suggesting a more industrial base), and is positively affected by the location of nearby colleges (which often serve as a proxy for other demand generators). The model is intended as a predictive tool and is not designed to show causal relationships.

\section{Developing a Decision Rule}

During the course of our analysis, we realized that being able to predict profitability accurately was not as important as being able to predict whether a site would be profitable or unprofitable. At the stage of site selection, La Quinta was not so concerned with exactly how profitable a site would be, but with whether the site would be good or bad. Because of this, we decided to use the regression model to develop a decision rule which could help the managers to determine whether a site would be successful.

To do this, we needed to define what was considered a good site. After consulting with La Quinta, we determined an acceptable level of profitability. We then classified all sites as being good (profitable) or bad (unprofitable) based on the criteria selected by management. A good site was defined as an inn with an operating margin of over 35 percent. Roughly 60 percent of the inns in the sample were considered good sites, while the remainder were considered poor sites. This definition of a good site could be changed if necessary.

We then used the regression model to predict profitability and developed a cutoff that gave the best results for predicting success or failure of a site. We then matched our profitability predictions against whether the sites were actually successful (based on 
management's definition). If we predicted that a site would be profitable, and the site was actually profitable, we considered it to be a successful decision. However, if we predicted that it would be profitable and it was in fact unprofitable, a false positive error had been made. Conversely, if we predicted that the site would be unprofitable, and it actually was unprofitable, a successful decision had been made. As in the false positive case, if we predicted that it would be unprofitable when it was in fact profitable, a false negative decision would occur. La Quinta was more concerned with keeping false positive rates (picking bad sites) to a minimum and was willing to accept a reasonable level of risk of rejecting good sites.

We then asked La Quinta to specify an acceptable level of risk of picking a bad site and gave them a decision rule that would satisfy this criteria. When using the model, the company would first use the regression model to predict profitability and then match this prediction against the decision rule. If the predicted profitability was higher than the decision rule, the decision was to accept the site, while if the prediction was lower than the decision rule, the decision was to reject the site. The risks of rejecting a good site and accepting a bad site associated with the use of this rule were known.

\section{Validation}

Although we were fairly confident of our model's robustness, we next tested the model's validity on a sample of inns we had set aside, and found predictions to be within the error ranges expected. In addition, we tested the model on all mature inns of La Quinta in a subsequent year, and we again found the error rates to be within the expected range [Kimes 1987], 
In 1987, La Quinta operated 151 mature inns. We collected current data on all inns including the 57 inns that had been used for the original analyses and model development. The 1987 data afforded us the opportunity to evaluate the 1987 decision model on an independent sample of 94 inns. With the exception of one case, error rates were within the expected range.

\section{Implementation of the Model}

La Quinta has since implemented the model on a LOTUS spreadsheet. It collects information on each of the independent variables, standardizes the data (using look-up tables), and calculates predicted profitability using the regression equation. It applies the decision rule and suggests "build" or "don't build." The decision model is intended to assist with decision making, not to supplant their current procedure.

In addition, we developed guide sheets for site selectors to use in the field, which list desirable ranges of values for different variables. In this way, site selectors can easily classify sites as low, medium, or high on individual variables, which facilitates the initial site screening process.

\section{Strategic Implications}

This study illustrates the marketing response of a successful service firm. It performed an in-depth analysis of its location decisions at a time when it expected rapid growth. By understanding the characteristics that make a site successful, the firm can be better prepared to select more successful sites in the future. 
In our initial study, conducted in the economic boom year of 1983, we selected occupancy as the independent variable to measure the sales potential of future sites for development. However, when these models were used to describe the data for the economic bust year of 1986 they were found to be inappropriate. This demonstrated lack of robustness led us to use operating margin as the independent variable. This independent variable is much more stable over the business cycle because it incorporates management's decision to use room rate to offset changes in economic fortunes. La Quinta could use flexible prices because it was positioned as an upscale budget-priced business hotel and thus did not have an image of the low-cost provider. Furthermore, during an economic downturn, business travelers become more price sensitive and this made La Quinta an attractive alternative to the major chains.

La Quinta has subsequently adopted these models and more sophisticated extensions into a decision-making process that is now based on collecting site data identified by our analysis as significant for predicting future profitability. The models are routinely used to screen potential real estate acquisitions for possible development. Sam Barshop, the founder and president of La Quinta, has accepted the validity of the models and no longer feels obliged to personally select the sites. Our model is not designed to replace the judgment of the site selectors, but rather to give them a tool to aid in the site selection decision. 
Table 1. Independent variables collected for the initial model building stage were classified as competitive, demand generator, demographic, market awareness, or physical site variables.

\begin{tabular}{|c|c|c|}
\hline Category & Name & Description \\
\hline \multirow[t]{6}{*}{ Competitive } & INNRATE & Inn price \\
\hline & PRICE & Room rate for the inn \\
\hline & RATE & Average competitive room rate \\
\hline & RMS1 & Hotel rooms within 1 mile \\
\hline & RMSTOTAL & Hotel rooms within 3 miles \\
\hline & ROOMSINN & Inn rooms \\
\hline \multirow[t]{18}{*}{ Demand Generators } & CIVILIAN & Civilian personnel on base \\
\hline & COLLEGE & College enrollment \\
\hline & HOSP1 & Hospital beds within 1 mile \\
\hline & HOSPTOTL & Hospital beds within 4 miles \\
\hline & HVYIND & Heavy industrial employment \\
\hline & LGTIND & Light industrial acreage \\
\hline & MALLS & Shopping mall square footage \\
\hline & MILBLKD & Military base blocked \\
\hline & MILITARY & Military personnel \\
\hline & MILTOT & MILITARY + CIVILIAN \\
\hline & OFC1 & Office space within 1 mile \\
\hline & OFCTOTAL & Office space within 4 miles \\
\hline & OFCCBD & Office space in CBD \\
\hline & PASSENGR & Airport passengers enplaned \\
\hline & RETAIL & Scale ranking of retail activity \\
\hline & TOURISTS & Annual tourists \\
\hline & TRAFFIC & Traffic count \\
\hline & VAN & Airport van \\
\hline \multirow[t]{3}{*}{ Demographic } & EMPLYPCT & Unemployment percentage \\
\hline & INCOME & Average family income \\
\hline & POPULACE & Residential population \\
\hline \multirow[t]{4}{*}{ Market Awareness } & AGE & Years inn has been open \\
\hline & NEAREST & Distance to nearest inn \\
\hline & STATE & State population per inn \\
\hline & URBAN & Urban population per inn \\
\hline \multirow[t]{4}{*}{ Physical } & ACCESS & Accessibility \\
\hline & ARTERY & Major traffic artery \\
\hline & DISTCBD & Distance to downtown \\
\hline & SIGNVIS & Sign visibility \\
\hline
\end{tabular}


Table 2. A summary of the variables that correlated with operating margin in 1983 and 1986.

\begin{tabular}{lcc} 
Variable & 1983 & 1986 \\
\hline ACCESS & .20 & \\
AGE & .29 & .49 \\
COLLEGE & & .25 \\
D1STCBD & & -.22 \\
EMPLYPCT & -.22 & -.22 \\
INCOME & & -.23 \\
MILTOT & & .22 \\
NEAREST & -.51 & \\
OFCCBD & .30 & .35 \\
POPULACE & .30 & .58 \\
PRICE & .38 & .27 \\
RATE & & -.33 \\
STATE & -.32 & \\
SIGNVIS & .25 & -.26 \\
TRAFFIC & .32 & \\
URBAN & -.22 &
\end{tabular}


Table 3. A summary of the t-test analysis for independent variables in 1983 and 1986. We defined a profitable inn as one with an operating margin of over 50 percent and an unprofitable inn as one with an operating margin of less than 30 percent.

19831986

\begin{tabular}{llrlr} 
Variable & Low & High & Low & High \\
\hline COLLEGE & 4.1 & 8.6 & 4.5 & 13.9 \\
DISTCBD & & & 5.8 & 3.9 \\
EMPLYPCT & 10.0 & 7.0 & 10.3 & 7.4 \\
HOSP1 & 59.0 & 177.0 & 49.0 & 1481.0 \\
HOSPTOTL & & & 874.0 & 2525.0 \\
MILTOT & 0.6 & 4.4 & 0.0 & 6.6 \\
NEAREST & 104.0 & 15.0 & & 7067.0 \\
OFC1 & 879.0 & 802.0 & 2293.0 & \\
OFCTOTAL & & & & 79.0 \\
PASSENGR & 2555.0 & 843.0 & & 1388.0 \\
POPULACE & & & 40.0 & \\
RMS1 & 1409.0 & 686.0 & 598.0 & \\
RMSTOTAL & 2983.0 & 2388.0 & & 233.0 \\
SIGNVIS & 0.5 & 0.9 & & 691.0 \\
STATE & 1428.0 & 459.0 & 898.0 & 101.0 \\
TOURISTS & 2156.0 & 218.0 & 389.0 & 478.0 \\
TRAFFIC & & & 73.0 & \\
URBAN & 518.0 & 233.0 & 477.0 &
\end{tabular}




\section{References}

Applebaum, William 1966, "Methods for determining store trade areas, market penetration and potential sales," Journal of Marketing Research, Vol. 3, No. 2, pp. 127-141.

Belsley, David A.; Kuh, Edwin; and Welsch, Roy E. 1980, Regression Diagnostics, John Wiley and Sons, New York.

Craig, C. Samuel; Ghosh, Avijit; and McLafferty, Sara 1984, "Models of the retail location process: A review," Journal of Retailing, Vol. 60, No. 1, pp. 5-36.

Huff, David L. 1962, "A probabilistic analysis of consumer behavior," in Emerging Perspectives in Marketing, ed. W. D. Decker, American Marketing Association, Chicago, Illinois.

Kimes, Sheryl E. 1987, "Location analysis in the lodging industry," PhD diss., University of Texas-Austin.

Langeard, Eric and Eiglier, Pierre 1983, "Strategic management of service development," in Emerging Perspectives on Services Marketing, eds. Berry et al., American Marketing Association, Chicago, Illinois, pp. 68-72.

Tallis, Alan 1983, Trade Area Analysis (professional report) University of Texas-Austin.

Tukey, John W. 1977, Exploratory Data Analysis, Addison-Wesley Publishing Company, Reading, Massachusetts. 